\title{
Grazing of Arctic under-ice amphipods on sea-ice algae
}

\author{
Iris Werner* \\ Sonderforschungsbereich 313, University of Kiel, Institute of Polar Ecology, Wischofstr. 1-3, D-24148 Kiel, Germany
}

\begin{abstract}
Feeding of the Arctic under-ice amphipods Apherusa glacialis, Onisimus spp. and Gammarus wilkitzkii on sea-ice algae was investigated in laboratory experiments. The specific ingestion rates of algal biomass declined with increasing size of the species (A. glacialis, 51; Onisimus spp., 11; G. wilkitzkii, $2 \mathrm{ng}$ chl a equival. $\mathrm{mg}^{-1}$ dry mass $\mathrm{d}^{-1}$ ). Juveniles of Onisimus spp. and $G$. wilkitzkii had specific rates that were 1 to 2 orders of magnitude higher than those of the respective adults. Calculations of the carbon budget and observations of amphipods behaviour indicate that A. glacialis is predominantely herbivorous, whereas Onisimus spp. are herbivorous/detritivorous, and G. wilkitzkii is herbivorous/detritivorous/carnivorous. The grazing impact on the ice-algal standing stock at the ice underside in summer, estimated for 2 different areas in the Arctic, was low $1.1 \% \mathrm{~d}^{-1}$ in the Laptev Sea, $2.6 \% \mathrm{~d}^{-1}$ in the Greenland Sea), indicating that food is not a limiting factor in this habitat.
\end{abstract}

KEY WORDS: Ingestion rate - Grazing impact Sea ice Amphipoda - Arctic

\section{INTRODUCTION}

In the Arctic Ocean, sea ice covers an area of $7 \times$ $10^{6} \mathrm{~km}^{2}$ in summer and $14 \times 10^{6} \mathrm{~km}^{2}$ in winter (Maykut 1985). The ice interior provides a unique habitat for a diverse and specialized flora and fauna, ranging from bacteria to metazoans (e.g. Horner 1976, Carey \& Montagna 1982, Cross 1982, Gradinger \& Zhang 1997). Many sea-ice organisms have their abundance and biomass maxima in the lowermost centi- to decimetres of the ice (Booth 1984, Grainger \& Mohammed 1986, Gradinger et al. 1991). The ice underside is inhabited by several amphipod species, of which Apherusa glacialis (Hansen), Onisimus glacialis (Sars), $O$. nanseni (Sars), and Gammarus wilkitzkii (Birula) are the most common species. They have been reported from almost all areas of the Arctic Ocean, being distributed by the drifting sea ice (Lønne \& Gulliksen 1991a, b, Carey 1992, Werner 1997). Abundances range from single specimens to several hundreds $\mathrm{m}^{-2}$ ice underside (Lønne \& Gulliksen 1991a, b, Poltermann 1997, Werner 1997).

•E-mail: iwerner@ipoe.de
Although it is generally accepted that the Arctic under-ice amphipods play an important role as a trophic link between the sea ice and the water column, little information is available on their feeding ecology. It has been suggested that the amphipods graze on ice algae at the ice underside (Cross 1982, Carey 1985, Gulliksen \& Lonne 1989). However, only a few studies have extensively dealt with this issue. Most investigations focused on gut content analyses (Bradstreet \& Cross 1982, Grainger et al. 1985), and additional foodchoice experiments were conducted by Poltermann (1997). Ice algae were found in the guts of Apherusa glacialis, Onisimus spp., and Gammarus wilkitzkii during all these studies, but no attempt was made to quantify the actual feeding activities.

This study, prompted by the obvious lack of basic data, aimed to (1) investigate the feeding habits of the individual species, (2) determine their nutritional demands, and (3) estimate the grazing impact on the ice-algal standing stock at the ice underside. For these purposes, ingestion rate was chosen as the major parameter to be determined in experiments, because it is the most meaningful measure for comparing different feeding habits (Omori \& Ikeda 1984) and is the largest and most important term in all metabolic equations 
(Clarke et al. 1988). The ingestion rate is also the basis for estimating the impact of a given species on its ecosystem (Peters 1983).

\section{METHODS}

Experimental animals. Experiments on the grazing activity of Arctic under-ice amphipods were carried out onboard RV 'Polarstern' during the expeditions ARK XI/1 (Laptev Sea and adjacent Arctic Ocean) and ARK XI/2 (Greenland Sea and Fram Strait) in summer and autumn 1995. Under-ice amphipods (Apherusa glacialis, Onisimus glacialis, $O$. nanseni, Gammarus wilkitzkii) were sampled at ice stations by means of an under-ice pumping system (Werner 1997) and from ice cores drilled with a SIPRE corer, as well as with Bongo nets (200 and $310 \mu \mathrm{m}$ mesh size) at partially ice-covered plankton stations. They were reared in filtered (0.8 $\mu \mathrm{m}$ pore size) seawater, at $0 \pm 1{ }^{\circ} \mathrm{C}$ temperature and 30 to $34 \%$ salinity. White styrofoam pieces floating on the water surface provided a substrate for the amphipods to attach to. Observations of behaviour were made during the rearing period of several months. For the experiments, only amphipods with a healthy and active appearance were chosen from the stock, which comprised amphipods from different stations. Species of Onisimus were not separated in the experiments. Prior to the experiments, the amphipods were not fed for 2 wk.

Ice-algal cultures. Mixed ice-algal cultures were established to provide food for rearing and feeding experiments. As a source, undersides (bottom $20 \mathrm{~cm}$ ) of ice cores were melted in a surplus of filtered $10.8 \mu \mathrm{m}$ pore size) seawater at $0^{\circ} \mathrm{C}$. To remove larger grazers, the material was screened through a $50 \mu \mathrm{m}$ sieve. The cultures were grown with Drebes standard culture media 1 to 6 (Von Stosch \& Drebes 1964) at $0 \pm 1^{\circ} \mathrm{C}$ and under permanent light. They were diluted with nutrient-enriched, filtered seawater (salinity 28 to $32 \%$ ) every 1 to $2 \mathrm{wk}$. The cultures could be maintained in growing condition (chl a: phaeopigments $=5: 1$ ), mostly at a biomass concentration of 30 to $50 \mu \mathrm{g} \mathrm{chl} \mathrm{a}$

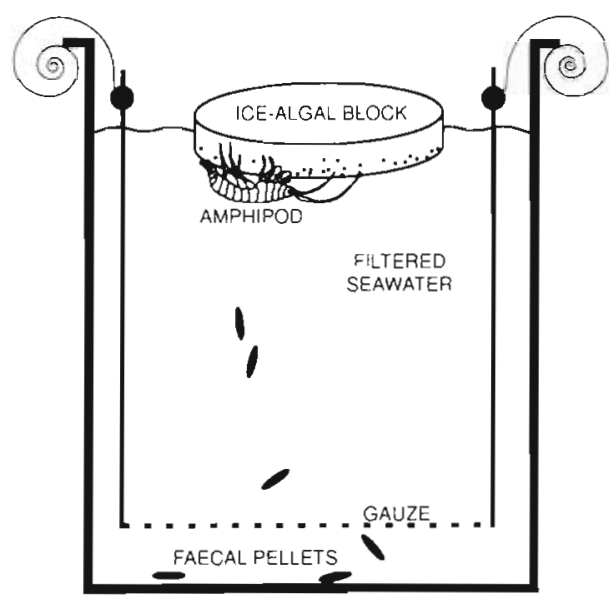

Fig. 1. Experimental set-up designed for grazing experiments with Arctic under-ice amphipods. Volume of filtered seawater in the vial is $1.5 \mathrm{l}$. The frozen ice-algal block serves as a substrate and contains the food sourre; the inserted tube covered by gauze at the lower end prevents coprophayy

equival. $\mathrm{I}^{-1}$, for several months. They consisted mainly of small pennate diatoms such as Nitzschia spp. from the $N$. frigida/neofrigida group, Fragilariopsis spp. and others (R. Horner pers. comm.), but also contained a variety of photo- and heterotrophic flagellates (Ikävalko \& Gradinger 1997).

Ingestion rates. In order to determine the ingestion rates of under-ice amphipods, ice algae frozen in seaice blocks were offered as food (Fig. 1). Defined volumes $(100 \mathrm{ml})$ of the ice-algal culture with a known concentration of chl a equivalents were frozen solid $\left(-10\right.$ to $-18^{\circ} \mathrm{C}$ for $\left.12 \mathrm{~h}\right)$ in round aluminium dishes (10 $\mathrm{cm}$ in diameter, $2 \mathrm{~cm}$ high). Experimental amphipods were placed in plastic vials filled with filtered seawater $\left(0 \pm 1^{\circ} \mathrm{C}\right.$ temperature, 30 to $34 \%$ salinity $)$. A total of 20 experiments were set up, applying an experimental design with species and stages as treatments, as well as controls without amphipods to assess the role of micrograzers in the culture (Table 1). All experiments were run simultaneously, with 1 frozen ice-algal block placed into each experimental vial. Experiments were

Table 1. Arctic under-ice amphipods. Length and dry mass of experimental animals (mean \pm standard deviation), number of experimental replicates for each species and number of specimens per replicate

\begin{tabular}{|lcccc|}
\hline Species & Length $(\mathrm{mm})$ & Dry mass $(\mathrm{mg})$ & Replicates & Specimens per replicate \\
\hline Apherusa glacialis, adult & $8.8 \pm 1.7$ & $2.5 \pm 1.9$ & 5 & $7-8$ \\
Onisimus spp., adult & $13.7 \pm 2.8$ & $12.1 \pm 5.1$ & 4 & $7-8$ \\
Onisimus spp., juvenile & $5.7 \pm 1.0$ & $1.1 \pm 0.5$ & 1 & 11 \\
Gammarus wilkitzkii, adult & $39.9 \pm 5.1$ & $121.7 \pm 62.5$ & 4 & 1 \\
G. wilkitzkii, juveniles & $5.5 \pm 0.6$ & $0.3 \pm 0.2$ & 3 & $4,27,27$ \\
Control & - & - & 3 & 0 \\
\hline
\end{tabular}


terminated when the ice had melted (after 36 to $72 \mathrm{~h}$ ). Experimental amphipods were removed from the vials, recorded on video tape for length measurements (Werner 1997), rinsed with freshwater and frozen $\left(-30^{\circ} \mathrm{C}\right)$ for later determination of dry mass after freeze-drying. Seawater from the experimental vials was immediately filtered on Whatman GF/F filters and stored at $-18^{\circ} \mathrm{C}$ for fluorometrical analyses of chl a equivalents according to Arar \& Collins (1992). The difference between the initial algal biomass offered to the experimental amphipods and the remaining algal biomass yielded the amount consumed (calculated as ingestion of chl a equivalents per individual, as well as per mg dry mass). Conversion to carbon units was calculated applying a carbon:chl a equival. ratio of 100 determined for the ice-algal culture (Werner 1997), and an estimated amphipod carbon content of $40 \%$ of dry body mass (Peters 1983, Drits et al. 1993).

Grazing impact. The grazing impact imposed on the ice-algal standing stock by the under-ice amphipods in summer was calculated for 2 different regions: (1) Lapter Sea and adjacent Arctic Ocean, and (2) Greenland Sea and Fram Strait. The ice-algal biomass (as chl a equival. $\mathrm{m}^{-2}$ ) in the lowermost $2 \mathrm{~cm}$ of the ice was measured in ice-core samples from 17 stations in the Laptev Sea (Werner 1997), and from 9 stations in the Greenland Sea (R. Gradinger pers. comm.). Amphipod abundances at the ice underside were determined from under-ice video recordings at 12 stations in the Laptev Sea and at 8 stations in the Greenland Sea (Werner 1997). These field data were combined with the experimentally derived ingestion rates of adult amphipods for the estimation of their grazing impact.

Statistical evaluation. The distribution of the experimental results was tested for normality using the Kolmogorov-Smirnov one-sample test. When appropriate, the Lilliefors modification for small sample sizes was applied. Since most experimental data were normally distributed, mean values and standard deviations (or standard errors) were calculated. Differences between species were tested by means of a factorial analysis of variance (ANOVA) and Fishers PLSD post hoc test. Differences between adults and juveniles were analyzed by an unpaired Student's $t$-test.

\section{RESULTS}

\section{Observations of feeding behaviour}

During the rearing period, several specimens of Onisimus spp. were observed to feed on dead or moribund congeners. Adults of Gammarus wilkitzkii frequently attacked living amphipods, including conspe- cific animals, which were firmly held in a precopulalike grip and eaten, with the predator being attached to the ice underside. In order to prevent cannibalism, adults of this species had to be kept as single specimens in the aquaria and during the experiments. In contrast, Apherusa glacialis was never observed to consume animal food. All species of under-ice amphipods studied reacted to the presence of ice by swimming upward and attaching to the ice underside. Grazing activity at the ice-algal blocks was observed in all species as well. Since the experimental set-up prevented feeding on material which had sunk to the bottom of the vial (Fig. 1), all ingested algal biomass could only be grazed directly from the ice. Most animals had dark guts after the experiments, and the presence of faecal pellets indicated feeding activity as well.

\section{Ingestion rate}

The ice-algal culture offered to the experimental amphipods as food had a mean concentration of $62.9 \pm$ $3.4 \mu \mathrm{g}$ chl a equival. $\mathrm{l}^{-1}(\mathrm{n}=3)$, resembling concentrations observed in situ in the lowermost $2 \mathrm{~cm}$ of the ice, e.g. in the Laptev Sea and the adjacent Arctic Ocean in summer (Werner 1997). In the control treatments (without amphipods), the decrease of algal biomass was very low in the course of the experiment, with a mean value of $9.9 \pm 6.9 \mathrm{ng}$ chl a equival. $\mathrm{d}^{-1}(\mathrm{n}=3)$. Thus, the influence of micrograzers in the frozen icealgal culture was considered to be negligible for the further evaluation of the experiments.

Considerable differences in feeding rates of algal biomass were found between species (Fig. 2). The

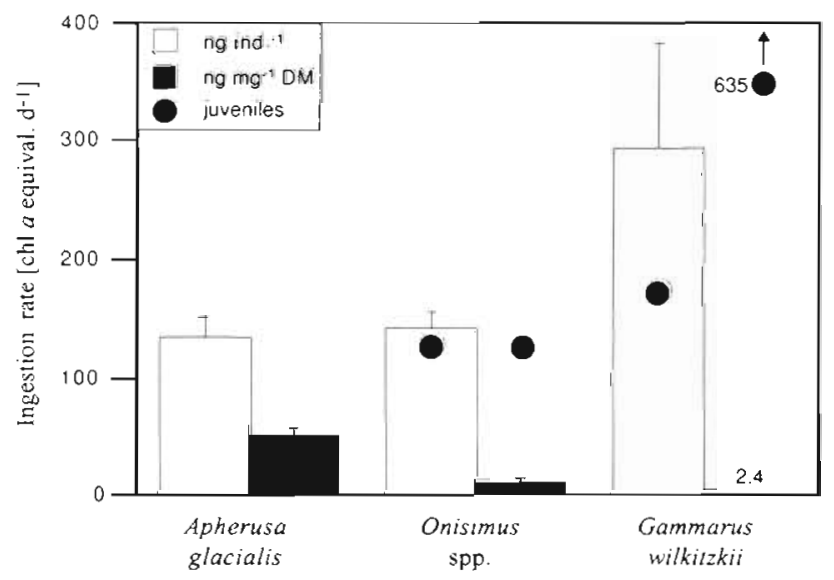

Fig. 2. Arctic under-ice amphipods (adults and juveniles). Rates of algal biomass ingestion. Bar heights show mean values for adults, shaded dots show values for juveniles (see Table 1). Error bars indicate standard errors. DM: dry mass 
mean individual ingestion rates were nearly the same for Apherusa glacialis and Onisimus spp. (131 and $138 \mathrm{ng}$ chl a equival. ind. ${ }^{-1} \mathrm{~d}^{-1}$, respectively), but it was 2 times higher in the much larger amphipod Gammarus wilkitzkil ( $288 \mathrm{ng} \mathrm{chl}$ a equival. ind.$^{-1} \mathrm{~d}^{-1}$ ). However, no significant effect of species was revealed by ANOVA $\left(F_{2,10}=3.19, \mathrm{p}=0.085\right)$. Consequently, mean specific feeding rates of algal biomass, i.e. those standardized to dry body mass (DM) of the amphipods, decreased with increasing size of the species. The smallest species, $A$. glacialis, had the highest mean ingestion rate, $51 \mathrm{ng}$ chl a equival. $\mathrm{mg}^{-1} \mathrm{DM} \mathrm{d}^{-1}$, followed by Onisimus spp. with a mean value of $11 \mathrm{ng}$ chl a equival. $\mathrm{mg}^{-1} \mathrm{DM} \mathrm{d}^{-1}$. The largest species, $G$. wilkitzkij, ingested on average only $2 \mathrm{ng} \mathrm{chl}$ a equival. $\mathrm{mg}^{-1} \mathrm{DM} \mathrm{d} \mathrm{d}^{-1}$. The effect of species on the specific ingestion rate was highly significant as shown by ANOVA $\left(F_{2,10}=39.69, \mathrm{p}<0.001\right)$. In particular, significant differences between the feeding rates of $A$ glacialis and Onisimus spp. $(\mathrm{p}<0.001)$, and between A. glacialis and $G$. wilkitzkii $(\mathrm{p}<0.001)$ were found.

The experiments on the feeding rates of juvenile Onisimus spp. and Gammarus wilkitzkii yielded considerable stage-dependent differences (Fig. 2). Juvenile individuals of Onisimus spp. ingested only slightly less algal biomass, $115 \mathrm{ng}$ chl a equival. ind. ${ }^{-1} \mathrm{~d}^{-1}$, than adults (138 ng chl a equival ind.$\left.^{-1} \mathrm{~d}^{-1}\right)$. However, their specific ingestion rate, $107 \mathrm{ng}$ chl a equival. $\mathrm{mg}^{-1} \mathrm{DM}$ $\mathrm{d}^{-1}$, was 1 order of magnitude higher as compared to the adults ( $11 \mathrm{ng}$ chl a equival. $\mathrm{mg}^{-1} \mathrm{DM} \mathrm{d}^{-1}$ ). The difference in feeding rates of juvenile and adult $G$. wilkitzkii was even more pronounced. Despite the large difference in size, juveniles and adults ingested a comparable and not significantly different amount of algal biomass in absolute terms $(171$ and $288 \mathrm{ng}$ chl a equival. ind ${ }^{-1} \mathrm{~d}^{-1}$, respectively). The specific ingestion rates were more than 2 orders of magnitude higher for the juveniles than for the adults of this species (635 vs 2 ng chl a equival. $\mathrm{mg}^{-1} \mathrm{DM} \mathrm{d}^{-1}$ ). This pronounced difference was significant $(t=2.88, \mathrm{p}=0.035$ )

The specific carbon uptake from the offered food source illustrated the differences between species and stages as well. Apherusa glacialis consumed the equivalent of approximately $1.3 \%$, adult Onisimus spp. $0.3 \%$, juvenile Onisimus spp. $2.7 \%$, adult Gammarus wilkitzkii $<0.1 \%$ and juvenile $G$. wilkitzkil $15.8 \%$ of their body mass (in carbon units) per day through feeding on the ice-algal cultures in the experiments

\section{Grazing impact}

Calculations of the populations' feeding pressure indicate that the grazing impact of adult under-ice amphipods on the ice-algal standing stock during summer was generally low (Fig. 3). As a function of mean abundances, which were different in the 2 areas studied, the total grazing impact of all species of under-ice amphipods was about twice as high in the Greenland Sea as in the Laptev Sea (2.6 vs $1.1 \%$ of the ice-algal standing stock per day). Apherusa glacialis had the highest grazing impact in the Greenland Sea, but the lowest in the Laptev Sea. There, Gammarus wilkitzkii was the most important grazer on ice algae among the under-ice amphipods, though in absolute terms it had a higher impact in the Greenland Sea. The grazing impact of Onisimus spp. was relatively low in both regions.

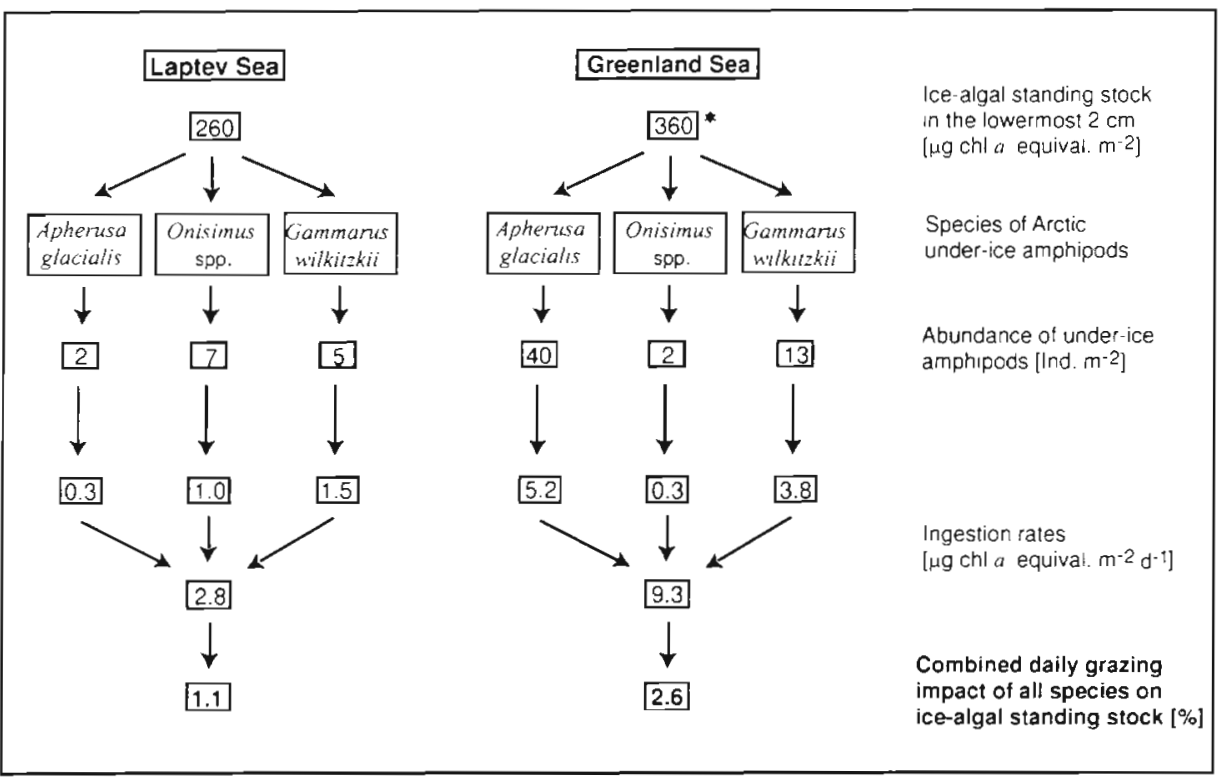

Fig. 3. Grazing impact of adult Arctic under-ice amphipods on the ice-algal standing stock in the Laptev Sea and in the Greenland Sea. Values are means. - R. Gradinger (pers. comm.) 


\section{DISCUSSION}

\section{Methods}

In order to obtain experimental results that are transferable to nature to a satisfying degree, the experimental conditions should resemble the natural conditions as closely as possible, a requirement which is especially difficult to meet for work with sea-ice organisms (Weissenberger 1992, Poltermann 1997). During the present experiments, a thorough attempt was made to provide the under-ice amphipods with as many 'natural' conditions as possible (Werner 1997), with frozen sea-ice blocks as substrate, natural seawater of temperatures and salinities very similar to the field conditions, and food offered in the same way as in the field, i.e. frozen into the ice. A similar technique has already been successfully used in studying underice grazing behaviour of Antarctic krill Euphausia superba (Stretch et al. 1988). It is, however, not understood as yet whether the Arctic under-ice amphipods only scrape the material off the ice underside, or whether they are also able to filter suspended particles from the water, as has been suggested by Poltermann (1997).

\section{Ingestion rates and feeding habits}

The grazing experiments corroborated the hypothesis that all species of Arctic under-ice amphipods studied feed on ice-algae at the ice underside. The observed differences in ingestion rates point out the different feeding habits of the species. Apherusa glacialis showed the highest specific ingestion rate of algal biomass. Conversion to carbon units and comparison with the carbon demand derived from respiration measurements indicate that the offered ice-algal food was fully adequate to meet nutritional demands of this species (Table 2). As a rule, the ingestion rate of exotherms is 2 to 4 times higher than the standard metabolic rate (Peters 1983). A. glacialis never consumed animal food (this study) and is usually not

Table 2. Arctic under-ice amphipods (adults). Specific carbon demand for respiration and carbon uptake by feeding on ice algae in experiments. DM: dry mass

\begin{tabular}{|lccc|}
\hline Species & $\begin{array}{c}\text { Respiration } \\
\left(\mu g \mathrm{C} \mathrm{mg}^{-1}\right.\end{array}$ & $\begin{array}{c}\text { Ingestion } \\
\left.\mathrm{DM} \mathrm{d}^{-1}\right)\end{array}$ & Feeding habit \\
\hline Apherusa glacialis & 2.3 & 5.1 & $\begin{array}{c}\text { Herbivorous } \\
\text { Onisimus spp. }\end{array}$ \\
Gammarus wilkitzkii & 0.0 & 1.1 & $\begin{array}{c}\text { Herbi-/detritivorous } \\
\text { Herbi-/detriti-/carnivorous }\end{array}$ \\
'Calculated according to data from Aarset \& Aunaas (1990), Aarset (1991)
\end{tabular}

attracted to baited traps (Poltermann 1997), and mostly algal material and detritus are found in the guts (Bradstreet \& Cross 1982, Poltermann 1997). It is therefore concluded that $A$. glacialis is a predominantly herbivorous species.

For adult Onisimus spp., the ice-algal food ingested during experiments would be just sufficient to meet the carbon demand for respiration (Table 2). Since reproduction and growth will require additional food uptake, the amphipods then have to ingest more algal biomass or exploit other sources. Besides ice algae (Bradstreet \& Cross 1982), animal remains hàve also been found in the guts of Onisimus spp. (Grainger et al. 1985, Poltermann 1997). Onisimus spp. were observed to feed on dead or moribund amphipods and are attracted to baited traps, but have rarely been observed to attack live animals (Poltermann 1997, this study). It is therefore suggested that Onisimus spp. (O. glacialis, $O$. nanseni) are omnivorous, with ice-algae and detritus (both plant and animal material) being major food items.

Adults of Gammarus wilkitzkii showed the lowest specific ingestion rates of algal biomass, which were equivalent to only a quarter of the respiration rate (Table 2). Although the presence of ice algae in the guts of $G$. wilkitzkii has been documented, detritus and animal remains, mainly from crustaceans, usually had a higher share (Bradstreet \& Cross 1982, Poltermann 1997). Moreover, $G$. wilkitzkii is commonly attracted to baited traps, and clearly exhibited a predatory behaviour, including cannabalism (Poltermann 1997, this study). It is therefore concluded that $G$. wilkitzkii is an omnivorous-carnivorous species with a wide spectrum of food sources. This species probably cannot rely on ice algae alone, unlike Apherusa glacialis and Onisimus spp.

Juveniles of Onisimus spp. and Gammarus wilkitzkii showed ingestion rates of algal biomass 1 and 2 orders of magnitude higher, respectively, as compared to the adults. This can be explained by the well-known, general relationship between metabolism and body size (Peters 1983), as has also been shown e.g. for Antarctic ice krill Euphausia crystallorophias (Pakhomov \& Perissinotto 1996) and several species and developmental stages of Antarctic copepods (Atkinson 1994). Body size may also have played a role in the interspecific differences found between under-ice amphipods with respect to ingestion and respiration rates (Aarset \& Aunaas 1990, Aarset 1991). It has been demonstrated for subarctic lysianassoid amphipods, including species of the genus Onisimus, that the specific respiration rate 
declines with body mass (Christiansen \& Diel-Christiansen 1993). On the other hand, the present findings for the juveniles probably indicate that younger amphipods exhibit a more herbivorous feeding habit than older animals, as has already been documented for other species of the generally omnivorous genus Gammarus (Steele \& Steele 1975).

Even those species and stages of under-ice amphipods that are considered to cover their metabolic requirements by ice algae (Apherusa glacialis, juvenile Onisimus spp. and juvenile Gammarus wilkitzkii) ingested a low proportion of their body carbon per day, compared to, for example, pelagic organisms from the same geographical area, e.g. 4 to $100 \%$ for Pseudocalanus spp. (Hanssen 1997 and references therein) and 6 to $91 \%$ for Calanus glacialis (Conover et al. 1986). Feeding on ice organisms, larvae of the Antarctic krill Euphausia superba ingest 2 to $44 \%$ of their body carbon per day, which probably covers the metabolic requirements for growth and development (Daly 1990). In general, Arctic under-ice amphipods seem to have low metabolic rates (Aarset \& Aunaas 1990), reflecting a more benthic type of physiology (Clarke \& Peck 1991). In contrast to pelagic organisms, which have to struggle constantly to avoid sinking and therefore spend a significant amount of energy on swimming (Kils 1981), under-ice amphipods do not swim long distances.

\section{Grazing impact}

The grazing impact of the under-ice amphipods on the ice-algal standing stock appeared to be low on average. However, at locations with maximum abundances of 700 to 800 amphipods $\mathrm{m}^{-2}$, the ice-algal biomass can be reduced by $30 \% \mathrm{~d}^{-1}$ (Werner 1997), and even by $63 \%$ in shallow coastal areas (Siferd et al. 1997). The total mean grazing impacts are in the same range as those imposed on melted-ice algae by pelagic sub-ice species (mainly Pseudocalanus spp. and Calanus glacialis) in spring $(0.5$ to $2.3 \%$; Tremblay et al. 1989). In the Antarctic, the daily grazing impact of ice krill Euphausia crystallorophias has been estimated to range between $<1$ and $5 \%$ of the phytoplankton standing stock (Pakhomov \& Perissinotto 1996).

Under-ice amphipods are certainly not the only consumers of ice algae. For instance, the sea-ice meiofauna is believed to exploit this food source as well (Grainger et al. 1985, Grainger \& Hsiao 1990, Grainger 1991). Additionally, several pelagic species depend on released ice algae as early food in spring (Conover et al. 1986, Runge \& Ingram 1988). In perennial sea ice, ungrazed organic matter can accumulate during the productive season and may represent an important food source for the ice fauna during winter (Melnikov 1997). However, it is not known as yet whether this organic matter is still accessible to the amphipods after growth of new ice has taken place at the ice underside. In the Antarctic, ice algae serve as an important food source for krill Euphausia superba in late winter and early spring (Marschall 1988, Stretch et al. 1988, Daly 1990).

\section{CONCLUSIONS}

(1) The observed differences in ingestion rates and feeding habits of the Arctic under-ice amphipods are a good example of niche separation of several species in the same habitat.

(2) The estimations of amphipod grazing impact on the ice-algal standing stock, which were well within the range of values for other important grazers in polar regions, indicate that there is no food limitation in this habitat, at least not during summer.

(3) Future studies should focus on the quantification of detritivorous and carnivorous food uptake by underice amphipods, as well as on their feeding ecology in winter.

Acknowledgements. I am grateful to the captains and crews of RV 'Polarstern' for their constant support during the cruises ARK XI $1+2$. The help of many colleagues on board and on the ice is sincerely acknowledged, in particular of $K$. Evers, $P$. Jochmann and F. Lindemann for technical support and assistence during field work. H. Auel provided numerous underice amphipods from his Bongo net samples, and A. Bartel conducted the measurements of the chlorophyll samples during ARK XI/1. Special thanks are due to $\mathrm{R}$. Gradinger for providing unpublished chlorophyll data. The manuscript benefited substantially from the constructive comments made by $R$. Gradinger, J. Ikävalko and D. Piepenburg. This is contribution 333 of the Sonderforschungsbereich 313, University of Kiel.

\section{LITERATURE CITED}

Aarset AV (1991) The ecophysiology of under-ice fauna. Polar Res 10(1):309-324

Aarset AV, Aunaas T (1990) Metabolic responses of the sympagic amphipods Gammarus wilkitzkii and Onisimus glacialis to acute temperature variations. Mar Biol 107 . $433-438$

Arar EJ, Collins GB (1992) In vitro determination of chlorophyll $a$ and phaeophytin $a$ in marne and freshwater phytoplankton by fluorescence. US EPA, Cincinnati

Atkinson A (1994) Diets and feeding selectivity among the epipelagic copepod community near South Georgia in surmmer. Polar Biol 14:551-560

Booth JA (1984) The epontic algal community of the ice edge zone and its significance to the Davis Strait ecosystem Arctic 37(3):234-243

Bradstreet MSW, Cross WE (1982) Trophic relationships at high Arctic ice edges. Arctic 35(1):1-1.2 
Carey AG (1985) Marine ice fauna: Arctic. In: Horner RA (ed) Sea ice biota. CRC Press, Boca Raton, FL, p 173-190

Carey AG (1992) The ice fauna in the shallow southwestern Beaufort Sea, Arctic Ocean. J Mar Syst 3:225-236

Carey AG, Montagna PA (1982) Arctic sea ice faunal assemblage: first approach to description and source of the underice meiofauna. Mar Ecol Prog Ser 8:1-8

Christiansen B, Diel-Christiansen S (1993) Respiration of lysianassoid amphipods in a subarctic fjord and some implications on their feeding ecology. Sarsia 78:9-15

Clarke A, Peck LS (1991) The physiology of polar marine zooplankton. Polar Res 10(2):355-369

Clarke A, Quetin LB, Ross RM (1988) Laboratory and field estumates of the rate of faecal pellet production by antarctic krill, Euphausia superba. Mar Biol 98:557-563

Conover RJ, Herman AW, Prinsenberg SJ, Harris LR (1986) Distribution of and feeding by the copepod Pseudocalanus under fast ice during the Arctic spring. Science 232: $1245-1247$

Cross WE (1982) Under-ice biota at the Pond Inlet ice edge and in adjacent fast ice areas during spring. Arctic 35(1): $13-27$

Daly KL (1990) Overwintering development, growth, and feeding of larval Euphausia superba in the Antarctic marginal ice zone. Limnol Oceanogr 35(7):1564-1576

Drits AV, Pasternak AF, Kosobokova KN (1993) Feeding, metabolism and body composition of the Antarctic copepod Calanus propinquus Brady with special reference to its life cycle. Polar Biol 13:13-21

Gradinger R, Spindler M. Henschel D (1991) Development of Arctic sea-ice organisms under graded snow cover. Polar Res 10(1):295-307

Gradinger R, Zhang Q (1997) Vertical distribution of bacteria in Arctic sea ice from the Barents and Laptev Seas. Polar Biol 17(5):448-454

Grainger EH (1991) Exploitation of Arctic sea ice by epibenthic copepods. Mar Ecol Prog Ser 77:119-124

Grainger EH, Hsiao SIC (1990) Trophic relationships of the sea ice meiofauna in Frobisher Bay, Arctic Canada. Polar Biol 10:283-292

Grainger EH, Hsiao SIC, Pinkewycz N, Mohammed AA, Neuhof $V(1985)$ The food of ice fauna and zooplankton in Frobisher Bay. Can Data Rep Fish Aquat Sci 55:81-67

Grainger EH, Mohammed AA (1986) Copepods in Arctic sea ice. Syllogeus 58:303-310

Gulliksen B, Lonne OJ (1989) Distribution, abundance, and ecological importance of marine sympagic fauna in the Arctic. Rapp PV Réun Cons Int Explor Mer 188:133-138

Hanssen H (1997) Das Mesozooplankton im Laptevmeer und östlichen Nansen Becken-Verteilung und Gemeinschaftsstrukturen in Spätsommer Ber Polarforsch 229: $1-131$

Horner RA (1976) Sea ice organisms. Oceanogr Mar Biol Annu Rev 14:167-182

Ikävalko J, Gradinger R (1997) Flagellates and heliozoans in the Greenland Sea ice studied alive using light micro-

Editorial responsibility: Otto Kinne (Editor),

Oldendorf/Luhe, Germany scopy. Polar Biol 17:473-481

Kils U (1981) Swimming behaviour, swimming performance and energy balance of Antarctic krill Euphausia superba. BIOMASS Sci Ser 3:1-121

Lønne OJ, Gulliksen B (1991a) On the distribution of sympagic macro-fauna in the seasonally ice covered Barents Sea. Polar Biol 11:457-469

Lonne OJ, Gulliksen B (1991b) Sympagic macro-fauna from multiyear sea-1ce near Svalbard. Polar Biol 11:471-477

Marschall HP (1988) The overwintering strategy of antarctic krill under the pack-ice of the Weddell Sea. Polar Biol 9: $129-135$

Maykut GA (1985) The ice environment. In: Horner RA (ed) Sea ice biota. CRC Press, Boca Raton, $\mathrm{FL}_{2}$ p 21-82

Melnikov IA (1997) The Arctic sea lce ecosystem. Gordon and Breach, Amsterdam

Omori M. Ikeda T (1984) Methods in marine zooplankton ecology. Wiley and Sons, New York

Pakhomov EA, Perissinotto R (1996) Antarctic neritic krill Euphausia crystallorophias: spatio-temporal distribution, growth and grazing rates. Deep Sea Res 43(1):59-87

Peters RH (1983) The ecological implications of body size. Cambridge University Press, Cambridge

Poltermann M (1997) Biologische und ökologische Untersuchungen zur kryopelagischen Amphipodenfauna des arktischen Meereises. Ber Polarforsch 225:1-170

Runge JA, Ingram RG (1988) Underice grazing by planktonic, calanoid copepods in relation to a bloom of ice microalgae in south-eastern Hudson Bay. Limnol Oceanogr 33(2): $280-286$

Siferd TD, Welch HE, Bergmann MA, Curtis MF (1997) Seasonal distribution of sympagic amphipods near Chesterfield Inlet, N.W.T., Canada. Polar Biol 18:16-22

Steele DH, Steele VJ (1975) The biology of Gammarus (Crustacea, Amphipoda) in the northwestern Atlantic. XI. Comparison and discussion. Can J Zool 53:1116-1126

Stretch JJ, Hamner PP, Hamner WM, Michel WC, Cook J, Sullivan CW (1988) Foraging behavior of Antarctic krill Euphausia superba on sea-ice microalgae. Mar Ecol Prog Ser 44:131-139

Tremblay C, Runge JA, Legendre L (1989) Grazing and sedimentation of ice algae during and immediately after a bloom at the ice-water interface. Mar Ecol Prog Ser 56 $291-300$

Von Stosch HA, Drebes G (1964) Entwicklungsgeschichtliche Untersuchungen an zentrischen Diatomeen. IV. Die Planktondiatomee Stephanopyxis turris, ihre Behandlung und Entwicklungsgeschichte. Helgoländer Wiss Meeresunters 11:209-257

Weissenberger J (1992) Die Lebensbedingungen in den Salzkanälchen des antarktischen Meereises. Ber Polarforsch 111:1-159

Werner 1 (1997) Ecological studies on the Arctic under-ice habitat-colonization and processes at the ice-water interface. Ber Sonderforschungsbereich 313 Univ Kiel $70: 1-167$

Submitted: September 10, 1997; Accepted: October 22, 1997 Proofs received from author(s): November 28, 1997 